\title{
Effectiveness and Safety of Autologous Stem Cell Mobilization with Granulocyte Colony Stimulating Factor in an Inpatient or Outpatient Setting
}

\author{
Yatarak veya Ayaktan Uygulanan Granülosit Koloni Uyarıcı Faktör ile Otolog Kök Hücre \\ Mobilizasyonunun Etkinliği ve Güvenliği
}

(D) Özcan ÇENELi, (D) Mehmet Ali KARASELEK, (D) Kazım ÇAMLI, (D) Atakan TEKINALP, (D) Sinan DEMIRCIOĞLU

Necmettin Erbakan University Meram Faculty of Medicine, Department of Internal Diseases, Konya, Turkey

\begin{abstract}
Aim: Autologous hematopoietic stem cell transplantation is the most frequently used treatment method in the treatment of lymphoma and myeloma patients. To apply this treatment method, first of all, a sufficient number of stem cells must be collected from the patient. With the development of apheresis methods and safe, effective mobilization methods, it is now possible to collect stem cells in an outpatient manner. In our study, we aimed to compare the efficacy and safety of outpatient based mobilization versus inpatient based mobilization of hematopoietic stem cells with granulocyte-colony stimulating factor (G-CSF) alone in patients with myeloma and lymphoma.

Materials and Methods: A total of 89 patients, including 54 patients who underwent outpatient and 35 patients who underwent inpatient based mobilization of stem cells with G-CSF alone were included in the study. Outpatient and inpatient based mobilization groups were compared in terms of efficacy and safety. Statistical analyses were performed with Jamovi 1.2.27 software. The Mann-Whitney $\mathrm{U}$ and chi-square tests were used to examine the differences. MANCOVA was used for univariate and multivariate statistical analysis of factors influencing mobilization.

Results: Three leukaphereses resulted in the collection of a mean $9.73 \times 10^{6} / \mathrm{kg}(4.5-16.5)$ CD34+ cells in the outpatient based mobilization group and a mean $11.8 \times 10^{6} / \mathrm{kg}(3.56-59)$ CD34+ cells in the inpatient based mobilization group $(p=0.14)$. Life-threatening side effects were not observed in any of the patients. Grade 1, 2 side effects were observed and there was no significant statistical difference between the two groups.

Conclusion: In this study, we found no significant difference in terms of efficacy and safety between the outpatient and the inpatient based mobilization group patients with myeloma and lymphoma who were mobilized with G-CSF. The results of our study show that outpatient based mobilization can be effectively and safely performed with g-csf, especially in patients who need autologous transplantation and avoid hospitalization, as in the current Coronavirus disease-2019 pandemic.
\end{abstract}

Keywords: Mobilization, granulocyte-colony stimulating factor, G-CSF, filgrastim, autologous hematopoietic stem cell mobilization, apheresis, leukapheresis

\section{ÖZ}

Amaç: Otolog hematopoetik kök hücre nakli lenfoma ve miyeloma hastalarının tedavisinde günümüzde sık kullanılan bir tedavi yöntemidir. Bu tedavi yönteminin uygulanabilmesi için öncelikle hastadan yeterli sayıda kök hücrenin toplanması gerekmektedir. Aferez ile güvenli ve etkili mobilizasyon yöntemlerinin gelişimiyle birlikte, hastane dışında kök hücre mobilizasyonu olası durumdadır. Çalışmamızda, miyeloma ve lenfoma hastalarında tek başına granülosit-koloni stimüle edici faktör (G-CSF) ile ayaktan ve hastanede yatarak hematopoetik kök hücre mobilizasyonunun etkinlik ve güvenliğini karşılaştırmayı amaçladık.

Gereç ve Yöntem: Elli dördü evde mobilizasyon uygulanan, 35'i hastanede mobilizasyon uygulanan hasta olmak üzere toplam 89 hasta çalışmaya alındı. Ayaktan ve yatarak mobilizasyon grupları etkinlik ve güvenlik yönünden karşılaştırıldı. İstatistiksel analizler Jamovi 1.2.27 yazılımı ile yapıldı. Farklılıkların değerlendirilmesinde Mann-Whitney U ve ki-kare testleri kullanıldı. Mobilizasyonu etkileyen faktörlerin istatistiksel analizi için ise MANCOVA kullanıldı.

Address for Correspondence: Özcan ÇENELi MD, Necmettin Erbakan University Meram Faculty of Medicine, Department of Internal Diseases, Konya, Turkey Phone: +90 5323629550 E-mail: cenelio@yahoo.com ORCID ID: orcid.org/0000-0003-2541-1335

Received: 16.03.2021 Accepted: 11.07.2021 
Bulgular: Üç lökoferez işlemi sonrasında, evde mobilizasyon grubunda ortalama 9,73×106/kg (4,5-16,5) CD34+ hücre, hastanede mobilizasyon grubunda ortalama $11,8 \times 10^{6} / \mathrm{kg}(3,56-59)$ CD34+ hücre toplandı $(p=0,14)$. Hiçbir hastada yaşamı tehdit edici bir yan etki gözlenmedi. Derece 1,2 yan etkiler gözlendi, iki grup arasında anlamlı istatistiksel farklılık yoktu.

Sonuç: Bu çalışmada G-CSF ile evde ve hastanede mobilizasyon uygulanan miyeloma ve lenfomalı hasta grupları arasında etkinlik ve güvenlik yönünden anlamlı farklılık saptanmadı. Çalışmamızın sonuçları günümüzdeki Koronavirüs hastalığı-2019 pandemisinde olduğu gibi, otolog transplantasyona ihtiyaç duyan ve özellikle hastaneye yatıştan kaçınan hastalarda g-csf ile ayaktan hasta bazında mobilizasyonun etkin ve güvenli bir şekilde yapılabileceğini göstermektedir.

Anahtar Kelimeler: Mobilizasyon, granülosit-koloni uyarıcı faktör, G-CSF, filgrastim, otolog hematopoetik kök hücre mobilizasyonu, aferez, lökoferez

\section{INTRODUCTION}

High-dose chemotherapy with autologous hematopoietic stem cell transplantation is frequently used in the treatment of patients with multiple myeloma (MM), non-Hodgkin's lymphoma (NHL), and Hodgkin's lymphoma $(\mathrm{HL})^{1-3}$. The first requirement for this treatment is the collection of a sufficient number of hematopoietic stem cells (HSCs). HSCs can be collected in two ways. Historically, HSCs were collected via multiple bone marrow aspirations from bilateral iliac crests. This method is used for limited indications today. The other way is the collection by leukapheresis after mobilization of HSCs into the peripheral blood. With the development of apheresis methods and safe, effective mobilization methods towards the end of the $20^{\text {th }}$ century, it is now possible to collect stem cells in an outpatient manner. Moreover, today, the Coronavirus disease-2019 (COVID-19) pandemic has made it clear that home remedies are necessary and may be needed in the future. In the setting of the COVID-19 pandemic, many patients avoid hospitalization. Therefore, outpatient based mobilization has become even more important.

In this retrospective study, we aimed to evaluate the effectiveness and safety of the HSC mobilization with granulocyte-colony stimulating factor (G-CSF) which was performed in the inpatient setting and in the outpatient setting for the patients who had hematological malignancies (MM, NHL, HL).

\section{MATERIALS AND METHODS}

\section{Demographic and Baseline Characteristics}

A total of 89 patients, including 54 patients who underwent HSCs outpatient based mobilization and 35 patients who underwent inpatient based mobilization with G-CSF alone, between 2012 and 2019, were included in the study. Our study objective was to evaluate the efficacy and safety of the HSC mobilization with G-CSF which was performed in the inpatient setting and in the outpatient setting for the patients who had hematological malignancies ( $\mathrm{MM}, \mathrm{NHL}, \mathrm{HL}$ ). In the outpatient based mobilization group, there were 39 patients with myeloma, 14 patients with NHL, (nine patients with diffuse large b-cell lymphoma (DLBCL), two patients with mantle cell lymphoma (MCL), two patients with follicular lymphoma, and one patient with MALT Iymphoma), and one patient with $\mathrm{HL}$.

The inpatient mobilization group included 24 patients with myeloma, five patients with NHL (two DLBCL, one $\mathrm{MCL}$, one peripheral t-cell lymphoma, one Burkitt lymphoma), and six patients with $\mathrm{HL}$.

The demographic and baseline characteristics, previous chemotherapy lines, HSC collection data of the patients are summarized in Table 1.

MM and lymphoma patients aged 18-75 years, mobilized only with G-CSF, were included in the study.

G-CSF (filgrastim) at a dose of $5 \mathrm{mcg} / \mathrm{kg}$ twice a day subcutaneously was administered as a mobilizing agent in all patients. Monitoring of peripheral blood CD34+ cells began on the fourth day of G-CSF administration and was performed daily. Leukapheresis was initiated if the CD34+ cell count had reached $>10 / \mu \mathrm{L}$ in the peripheral blood.

Before harvesting, all lymphoma patients had complete remission and their bone marrow was normocellular without lymphoma infiltration. Patients with myeloma also had a complete response or very good partial response. None of them had received immunomodulatory drugs (imid) treatment prior to mobilization. The peripheral stem cell harvesting was performed with an Amicus Fenwal apheresis device and calcium infused to prevent citrate-related complications. Venous access was provided via a central venous catheter in all patients. Age, sex, body weight, diagnosis, time to stem cell collection, total mononuclear cell count, and CD34+ cell count at the beginning of the collection, time to reach the target CD34+ cell count, product CD34+ cell counts, adverse reactions and complications were recorded.

All patients gave written informed consent. Our study was approved by the Ethics Committee of Necmettin Erbakan University Medicine Faculty with the 2019/2079 consent number.

\section{Statistical Analysis}

Statistical analyses were performed with Jamovi 1.2.27 software. The Mann-Whitney $\mathrm{U}$ test was used to examine 
the differences. A chi-square test was used to compare sex values between the groups. MANCOVA was used for univariate and multivariate statistical analysis of factors influencing mobilization. A p value of $<0.05$ was considered statistically significant.

\section{Efficacy Outcomes}

Minimal and target stem cell counts were considered $\geq 2 \times 10^{6}$ CD34+ cells $/ \mathrm{kg}$ and $\geq 4 \times 10^{6}$ CD34+ cells/kg for lymphoma patients and $\geq 4 \times 10^{6} \mathrm{CD} 34+$ cells $/ \mathrm{kg}$ and $\geq 6 \times 10^{6} \mathrm{CD} 34+$ cells $/ \mathrm{kg}$ for myeloma patients.

The inability to achieve minimal CD34+ cell counts after 3 courses of apheresis was defined as "mobilization failure".

\section{RESULTS}

Two patients, who failed a first mobilization attempt using G-CSF in the outpatient based mobilization group, were identified. Three patients had mobilization failure in the inpatient based mobilization group. So, in a total of 84 patients, including 52 patients who underwent outpatient based mobilization and 32 patients who underwent inpatient based mobilization, HSCs were collected successfully.
The effect of baseline status on the mobilization of CD34+ cells is shown in Table 2.

The target CD34+ cell count was achieved in one leukapheresis procedure in 15 patients, two procedures in 34 patients, and three procedures in three patients who performed outpatient based mobilization. For the patients who were inpatient based mobilized of HSCs, the target CD34+ cell count was reached in one procedure in nine patients, in two procedures in 18 patients, and three procedures in five patients. There was no significant difference between the groups $(p=0.39)$.

Total processed blood volume was $10,530+1,180 \mathrm{~mL}$ in the outpatient based mobilization group and $11220+1180 \mathrm{~mL}$ in the inpatient based mobilization group, and there was no statistically significant difference between the groups. Three leukaphereses resulted in the collection of a mean 9.73 (4.516.5) $\times 10^{6} / \mathrm{kg}$ CD34+cells in the outpatient based mobilization group and a mean $11.8(3.56-59) \times 10^{6} / \mathrm{kg}$ CD34+ cells in the inpatient based mobilization group $(p=0.14)$ (Table 3$)$.

Statistical analysis of factors influencing mobilization is presented in Table 4 and Figure 1.

\section{Table 1. Characteristic data of two groups}

\begin{tabular}{|l|l|l|}
\hline Characteristics & Outpatient mobilization & Inpatient mobilization \\
\hline Patients \# (n) & 54 & 35 \\
\hline Sex (M/F) & $28 / 26$ & $21 / 14$ \\
\hline Median age (min-max) & $60(32-69)$ & $57(29-71)$ \\
\hline Mean weight (kg) (min-max) & $74.4(44-102)$ & $73.8(51-120)$ \\
\hline Diagnosis of patients (n) & 39 & 24 \\
- MM & 14 & 5 \\
- NHL & 1 & 6 \\
- HL & & $2(1-2)$ \\
\hline Prior treatment lines, median (range) & $2(1-4)$ & $2(1-3)$ \\
- MM patients & $2(2-3)$ & $2(2-4)$ \\
- NHL patients & $2(2)$ & \\
- HL patients & & $5(3-9)$ \\
\hline Prior total chemotherapy cyclus, median (range) & $5(2-18)$ & $8(8-17)$ \\
- MM patients & $10(5-16)$ & $8(6-9)$ \\
- NHL patients & $8(8)$ & \\
- HL patients & & \\
\hline M/F: Male/female, min-max: Minimum-maximum, MM: Multiple myeloma, NHL: Non-Hodgkin's lymphoma, HL: Hodgkin's lymphoma & \\
\hline
\end{tabular}

\section{Table 2. Effect of baseline status on the mobilization of CD34 cells}

\begin{tabular}{|l|l|l|l|}
\hline Baseline status & Home mobilization group & Hospital mobilization group & p value \\
\hline $\mathrm{Hb}(\mathrm{g} / \mathrm{dL})[$ median (min-max)] & $12.5(9.3-15)$ & $11.4(8.5-16.1)$ & 0.50 \\
\hline Monocytes (/mcL) [median (min-max)] & $3.31(0.68-12)$ & $2.57(1.18-6.3)$ & 0.35 \\
\hline Prior chemotherapy lines [median (min-max)] & $2(1-4)$ & $2(1-4)$ & 0.68 \\
\hline Prior chemotherapy courses [median (min-max)] & $6(2-18)$ & $5(3-17)$ & 0.60 \\
\hline Hb: Hemoglobin, min-max: Minimum-maximum & \\
\hline
\end{tabular}


Table 3. Outcome of stem cell mobilization and harvesting

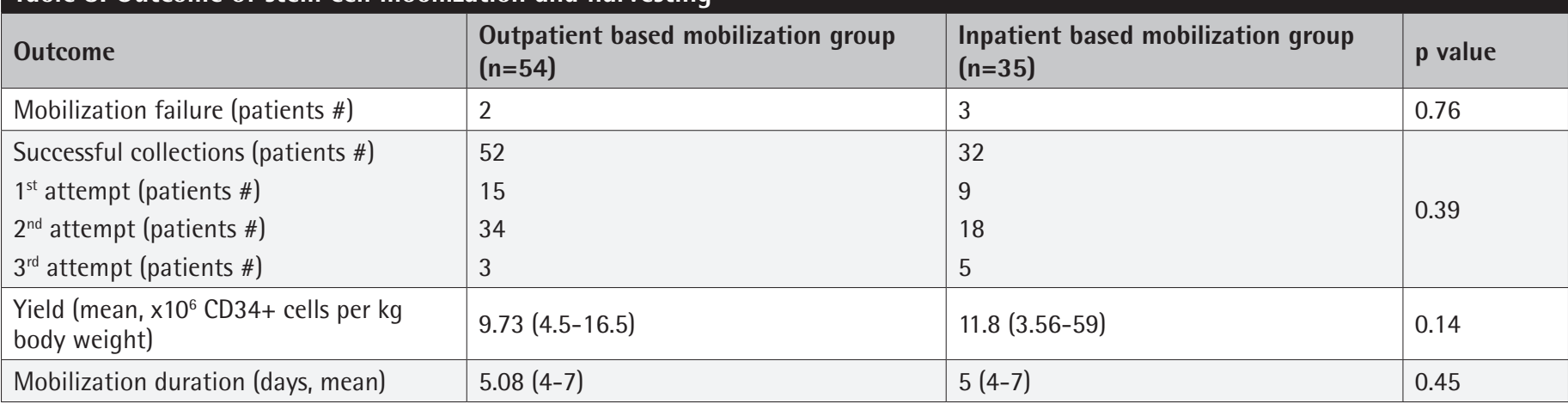

Table 4. Statistical analysis of factors influencing mobilization

\begin{tabular}{|c|c|c|c|c|c|c|c|c|c|c|c|c|}
\hline \multicolumn{6}{|c|}{ MANCOVA, multivariate tests } & \multicolumn{7}{|c|}{ Univariate tests } \\
\hline & Value & $\mathrm{F}$ & df1 & df2 & $\mathrm{p}$ & \multirow{3}{*}{ Groups } & Dependent variable & $\begin{array}{l}\text { Sum of } \\
\text { squares }\end{array}$ & df & $\begin{array}{l}\text { Mean } \\
\text { square }\end{array}$ & $\mathrm{F}$ & $\mathrm{p}$ \\
\hline Wilks' Lambda & 0.921 & 1.26 & 4 & 59 & 0.295 & & Hemoglobin (all patients) & 2.622 & 1 & 2.622 & 1.0111 & 0.319 \\
\hline Hotelling's Trace & 0.0857 & 1.26 & 4 & 59 & 0.295 & & ChemoLines (all) & 0.172 & 1 & 0.172 & 0.4069 & 0.526 \\
\hline \multirow{4}{*}{$\begin{array}{l}\text { Roy's Largest } \\
\text { Root }\end{array}$} & & & & & & \multirow{4}{*}{ Residuals } & Monocytes (all) & 249.857 & 62 & 4.030 & & \\
\hline & & & & & & & Hemoglobin (all patients) & 160.762 & 62 & 2.593 & & \\
\hline & & & & & & & ChemoLines (all) & 26.265 & 62 & 0.424 & & \\
\hline & & & & & & & Chemotherapy courses (all) & 715.788 & 62 & 11.545 & & \\
\hline
\end{tabular}

Life-threatening side effects were not observed in any of the patients. Common terminology criteria for adverse events (CTCAE) Grade 1,2 side effects, including nausea, bone pain, fatigue, and fever, were observed and there was no statistically significant difference between the two groups.

\section{DISCUSSION}

HSC mobilization for autologous transplantation can be performed using chemotherapy plus G-CSF or G-CSF alone ${ }^{4}$. Stem cell mobilization with chemotherapy + G-CSF is usually performed in the inpatient group. In our country, too, G-CSF alone or chemotherapy + G-CSF is used as the first mobilization protocol. Although less than stem cell mobilization with chemotherapy + G-CSF, side effects are also seen in stem cell mobilization with G-CSF alone. Bone pain, chest pain, fatigue, back pain, fever, nausea, splenomegaly, and skin rash are relatively common adverse reactions of G-CSF. Rarely, lifethreatening complications such as splenic rupture, stroke, myocardial infarction, anaphylaxis, aortitis, and capillary leak syndrome can occur, especially when used in high doses of $\mathrm{G}-\mathrm{CSF}^{5-7}$.

Spontaneous splenic rupture following the administration of G-CSF occurred very rarely both in autologous and allogeneic donors of peripheral stem cells. There are few case reports on this issue in the medical literature ${ }^{5-8}$. Inpatient based stem cell mobilization may be advantageous in terms of closely monitoring these side effects. However, life-threatening side effects are extremely rare. Patients should be informed about life-threatening side effects and their transportation facilities should be reviewed.

In the case report of Nuamah et al. ${ }^{7}$ about spontaneous splenic rupture and review of the literature, a healthy female allogeneic peripheral stem cell donor, who was given $20 \mathrm{mcg} /$ day G-CSF, developed a splenic rupture presenting with sudden sharp left upper quadrant pain, and emergent splenectomy was performed. In this publication, Nuamah et al. ${ }^{7}$ recommended close monitoring of patients, informing patients and donors about potential fatal complications, and avoiding vigorous activities because of the possibility of damage to the fragile spleen even from minor traumas. Similarly, in six cases of spontaneous splenic rupture, previously published by Falzetti et al. ${ }^{9}$, Dincer et al. ${ }^{10}$, Balaguer et al. ${ }^{11}$, Kasper et al. ${ }^{12}$, $0^{\prime}$ Malley et al. ${ }^{13}$, and Pitini et al. ${ }^{14}$, the dose of G-CSF used in these cases was between 5 and $20 \mathrm{mcg} /$ day. In the literature, most reported cases of splenic rupture had occurred within the days of apheresis and beyond. A definite correlation could not be established with the dose of G-CSF. 

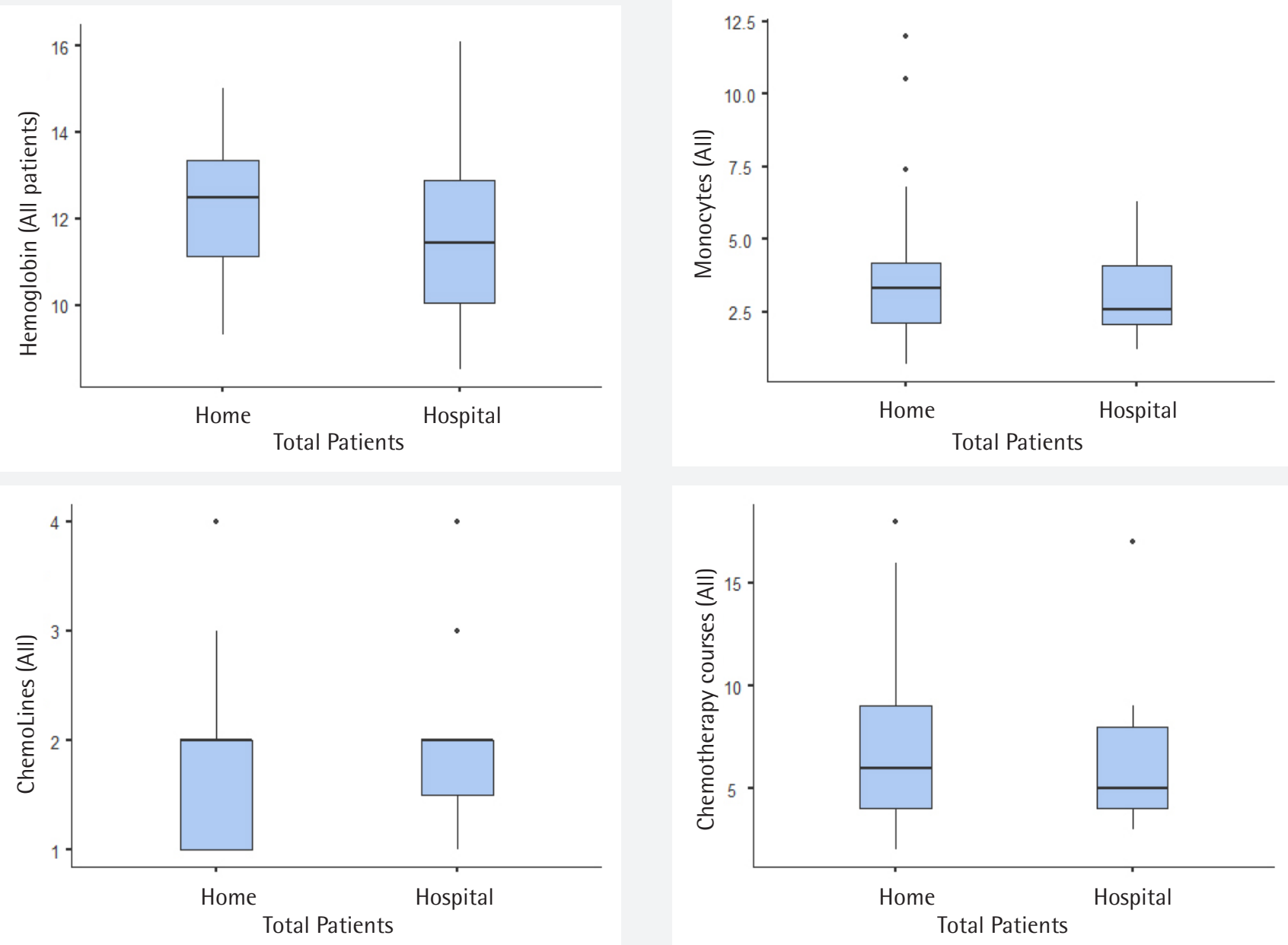

Figure 1. Plots graphics of mobilization influencing factors

\section{Study Limitations}

In our study, CTCAE Grade 1, 2 mild side effects were observed in both inpatient and outpatient mobilization patients (nausea, bone pain, fatigue, and fever). None of the rare lifethreatening side effects were observed in our study.

Nevertheless, the fact that it is not a prospective study and the relatively small number of patients are the limitations of our study. It was revealed from this study that there was no difference between the two groups, but this is not enough to say that there is no difference in terms of security as a whole.

\section{CONCLUSION}

In this study, we found no significant difference in terms of efficacy and safety between the outpatient based mobilization group and the inpatient based mobilization group in patients with MM and lymphoma, who were mobilized with G-CSF. The results of our study show that outpatient based mobilization can be performed with G-CSF, especially in patients who need autologous transplantation and avoid hospitalization, as in the current COVID-19 pandemic. However, although extremely rare, patients should be informed about possible fatal complications and rapid access to the hospital should be evaluated individually. Prospective, randomized studies are needed for clearer data on this subject.

\section{Ethics}

Ethics Committee Approval: The study were approved by the Necmettin Erbakan University University of Ethics Committee (protocol number: 2019/2079).

Informed Consent: Consent form was filled out by all participants.

Peer-review: Externally peer-reviewed.

\section{Authorship Contributions}

Surgical and Medical Practices: Ö.Ç., M.A.K., K.Ç., Concept: Ö.Ç., Design: Ö.Ç., Data Collection or Processing: Ö.Ç., M.A.K., 
K.Ç., A.T., Analysis or Interpretation: Ö.Ç., A.T., S.D., Literature Search: Ö.Ç., M.A.K., A.T., S.D., Writing: Ö.Ç.

Conflict of Interest: No conflict of interest was declared by the authors.

Financial Disclosure: The authors declared that this study received no financial support.

\section{References}

1. Palumbo A, Cavallo F, Gay F, Di Raimondo F, Ben Yehuda D, Petrucci MT, et al. Autologous transplantation and maintenance therapy in multiple myeloma. N Engl J Med. 2014;371:895-905.

2. Crump M, Neelapu SS, Farooq U, Van Den Neste E, Kuruvilla J, Westin J, et al. Outcomes in refractory diffuse large B-cell lymphoma: results from the international SCHOLAR-1 study. Blood. 2017;130:1800-8. Epub 2017 Aug 3. Erratum in: Blood. 2018;131:587-8.

3. Mohty $M$, Hubel $K$, Kroger $N$, Aljurf $M$, Apperley J, Basak GW, et al. Autologous haematopoietic stem cell mobilisation in multiple myeloma and lymphoma patients: a position statement from the European Group for Blood and Marrow Transplantation. Bone Marrow Transplant. 2014;49:86572.

4. Giralt S, Stadtmauer EA, Harousseau JL, Palumbo A, Bensinger W, Comenzo $\mathrm{RL}$, et al. International myeloma working group (IMWG) consensus statement and guidelines regarding the current status of stem cell collection and high-dose therapy for multiple myeloma and the role of plerixafor (AMD 3100). Leukemia. 2009;23:1904-12.

5. Kuendgen A, Fenk R, Bruns I, Dommach M, Schutte A, Engers $R$, et al. Splenic rupture following administration of pegfilgrastim in a patient with multiple myeloma undergoing autologous peripheral blood stem cell transplantation. Bone Marrow Transplant. 2006;38:69-70.
6. Filgrastim: Drug information, UpToDate 2019. Available from: https://www. uptodate.com/contents/search

7. Nuamah NM, Goker H, Kilic YA, Dagmoura H, Cakmak A. Spontaneous splenic rupture in a healthy allogeneic donor of peripheral-blood stem cell following the administration of granulocyte colony-stimulating factor ( $g$-csf). A case report and review of the literature. Haematologica. 2006;91(5 Suppl):ECR08.

8. Becker PS, Wagle M, Matous S, Swanson RS, Pihan G, Lowry PA, et al. Spontaneous splenic rupture following administration of granulocyte colony-stimulating factor (G-CSF): occurrence in an allogeneic donor of peripheral blood stem cells. Biol Blood Marrow Transplant. 1997;3:45-9.

9. Falzetti $F$, Aversa $F$, Minelli 0 , Tabilio A. Spontaneous rupture of spleen during peripheral blood stem-cell mobilisation in a healthy donor. Lancet. 1999;353:555.

10. Dincer AP, Gottschall J, Margolis DA. Splenic rupture in a parental donor undergoing peripheral blood progenitor cell mobilization. J Pediatr Hematol Oncol. 2004;26:761-3.

11. Balaguer H, Galmes A, Ventayol G, Bargay J, Besalduch J. Splenic rupture after granulocyte-colony-stimulating factor mobilization in a peripheral blood progenitor cell donor. Transfusion. 2004;44:1260-1.

12. Kasper C, Jones L, Fujita Y, Morgenstern GR, Scarffe JH, Chang J. Splenic rupture in a patient with acute myeloid leukemia undergoing peripheral blood stem cell transplantation. Ann Hematol. 1999;78:91-2.

13. O'Malley DP, Whallen M, Banks PM. Spontaneous splenic rupture with fatal outcome following G-CSF administration for myelodysplastic syndrome. Am J Hematol. 2003;73:294-5.

14. Pitini V, Ciccolo A. Arrigo C, Aloi G, Micali C, La Torre F. Spontaneous rupture of spleen during periferal blood stem cell mobilization in a patient with breast cancer. Haematologica. 2000;85:559-66. 